Dr IVAN M. BECIĆ, naučni saradnik

Institut za srpsku kulturu

UDK 336.743(497.1)"1919/1921"

Priština/Leposavić, 24. novembra bb

\title{
ZA DINAR ILI ZA KRUNU - KO JE DOBIO, A KO IZGUBIO*
}

\begin{abstract}
APSTRAKT: Kraljevina Srbija, Kraljevina Crna Gora i delovi AustroUgarske uneli su u Kraljevinu SHS i tri različita valutna sistema. Zajednička država podrazumevala je postojanje zajedničke valute, pa je osim izbora novčane jedinice trebalo utvrditi i međusoban odnos postojećih koji bi se primenjivao prilikom zamene. S obzirom na neveliku količinu crnogorskih perpera, bugarskih leva i nemačkih maraka, centralno pitanje bilo je utvrđivanje odnosa dinara Kraljevine Srbije i austrougarske krune. Primenjeno rešenje ne samo da je bilo predmet polemika u ekonomsko-političkim krugovima Kraljevine Jugoslavije, već je aktuelno i danas, gotovo vek posle stvaranja jugoslovenske države. $U$ radu su iznete teze i mišljenja koja su bila zastupljena, politička pozadina koja je stajala iza njih, a data je i analiza vrednosti dveju valuta $u$ momentu zamene i periodu koji mu je prethodio.
\end{abstract}

Ključne reči: Narodna banka, Austro-ugarska banka, dinar, kruna, podloga, opticaj

Kolanje nekoliko desetina valuta i moneta na prostoru Kneževine Srbije i potreba da se novčanično tržište uredi, kao i želja za isticanjem faktičke samostalnosti nagnale su kneza Mihaila da 1868. godine naloži da se u Beču otkuju apoeni od 1, 5 i 10 para u bakru. Pet godina kasnije zakonom je za novčanu jedinicu Srbije određen dinar, a sastav kovanica i njegova vrednost bili su određeni time što je Srbija pristupila Latinskoj uniji, koju su 1865. godine osnovale Belgija, Italija, Francuska i Švajcarska. ${ }^{1}$ U skladu

* Rad je deo projekta Materijalna i duhovna kultura Kosova i Metohije (178028) koji finansira Ministarstvo prosvete, nauke i tehnološkog razvoja Republike Srbije.

${ }^{1}$ Propisi Latinske unije predviđali su zakonsku stopu, stopu kovanja i vrste legura neplemenitih metala od kojih se kuje novac, odnosno njihove težine. Za osnovnu monetu (u ovom slučaju 1 dinar) propisana je težina od 5 grama i finoća 835/1000 srebra. Unija je prestala da funkcioniše 1925. godine. - Stevan M. Kukoleča, Organizaciono poslovni leksikon izraza, pojmova i metoda, Beograd 1986, 710. 
sa propisima Unije dinar u srebru pušten je u opticaj 1875, dok se u papiru pojavio 1876. godine. Vrednost dinara uglavnom je bila stabilna, a održavana je mogućnošću da se papirne novčanice zamene za metalnu podlogu. Zamena je vršena $u$ metalu na koji su novčanice glasile, a Privilegovana narodna banka Kraljevine Srbije ovu zakonsku obavezu prvi put je redukovala privremenom merom na dan objave rata Osmanskom carstvu 18. oktobra 1912. Redukcija se ogledala u tome što je kod podnetih novčanica na zamenu koje su glasile na zlato, $25 \%$ njihove vrednosti isplaćivano u srebru. Sa završetkom Balkanskih ratova Narodna banka vratila je princip zamene $\mathrm{u}$ pređašnje stanje 28. januara 1914. ukinuvši privremenu meru, ali je bila prinuđena da u potpunosti ukine zamenu novčanica za metal na dan mobilizacije za rat sa Austro-Ugarskom 27. jula 1914. ${ }^{2}$

Ukoliko bi se posmatrao odnos dinara u opticaju i njegove metalne i devizne podloge, moglo bi se zaključiti da je on u 1913. godini bio više nego zadovoljavajući i dinar se može smatrati stabilnom valutom u periodu pred izbijanje Prvog svetskog rata. Ukupan opticaj dinarskih novčanica bio je u vrednosti od 103.438.570, dok je podloga u zlatu, srebru i devizama bila u vrednosti 65.751 .136 dinara, tj. pokrivenost novčanica Narodne banke iznosila je $63,56 \% .^{3}$

\begin{tabular}{|c|l|l|l|l|l|l|}
\hline \multicolumn{3}{|c|}{ Opticaj } & \multicolumn{4}{c|}{ Podloga } \\
\hline $\begin{array}{l}\text { Novčanice } \\
\text { u zlatu }\end{array}$ & $\begin{array}{l}\text { Novčanice } \\
\text { u srebru }\end{array}$ & Ukupno & Zlato & Srebro & Devize & Ukupno \\
\hline 4.285 .280 & 99.153 .290 & 103.438 .570 & 57.842 .453 & 4.271 .903 & 3.636 .780 & 65.751 .136 \\
\hline
\end{tabular}

Za razliku od Srbije, Austrija (od 1867. Austro-Ugarska) nije imala prekid u izdavanju sopstvenog novca, pošto je od srednjeg veka neprekidno imala državno-pravni kontinuitet. Prvi papirni novac odštampan je 1761, a monopol emisije novčanica je od 1878. imala Austro-ugarska banka. Zakonom od 2. avgusta 1892. režim srebrnog važenja zamenjen je krunskom monetom kao novčanom jedinicom na bazi zlata. Vrednost krune utvrđena je na 1,05 vrednosti francuskog franka definisanog prema Latinskoj konvenciji. Pojavom krune počela je postepena zamena dotadašnjeg novca forinte i od 1. januara 1910. kruna je postala jedina važeća moneta. ${ }^{4}$ Iako

${ }^{2}$ Nemogućnost da se novčanice zamene za plemeniti metal na koji su glasile izazvala je nagli skok ažije (razlike između nominalne i kursne vrednosti) na zlato. Ona je 9. jula 1914. iznosila 0,50\%, septembra 1915. zbog spekulacije sa zlatom još uvek neutralnih Soluna, Bukurešta, Sofije dostigla je $25 \%$, a potom $30 \%$ a prilikom evakuacije iz Srbije $40 \%$. Visoka ažija primorala je vladu u Nišu da zabrani izvoz zlata. - Narodna banka 1884-1934, Beograd 1934, 96.

\footnotetext{
${ }^{3}$ Miodrag Ugričić, Novčani sistem Jugoslavije, Beograd 1967, 76.

${ }^{4}$ Isto, $81-86$.
} 
su finansijske prilike odavale utisak sređenosti, konvertibilnost krune nikada nije postojala, budući da je održavan dirigovan državni kurs, pošto su za platni promet upotrebljavane samo novčanice i sitan metalni novac, dok je zlato korišćeno samo za plaćanja u inostranstvu. Bez obzira na ograničenja, stanje Austro-ugarske banke uoči rata u pogledu odnosa podloge i novčanica u opticaju bilo je povoljno i stabilno i iznosilo je $58,28 \%$.

\begin{tabular}{|c|l|l|l|l|r|}
\hline \multicolumn{2}{|c|}{ Opticaj (u hiljadama kruna) } & \multicolumn{3}{c|}{ Podloga (u hiljadama kruna) } \\
\hline $\begin{array}{l}\text { Novčanice } \\
\text { u opticaju }\end{array}$ & $\begin{array}{l}\text { Obaveze } \\
\text { po viđenju }\end{array}$ & Ukupno & Zlato & $\begin{array}{l}\text { Srebro i zlatne } \\
\text { devize }\end{array}$ & Ukupno \\
\hline 2.494 .000 & 188.000 & 2.682 .000 & 1.241 .000 & 322.000 & 1.563 .000 \\
\hline
\end{tabular}

Rat je izazvao ukidanje konvertibilnosti mnogih valuta, budući da je zlato iščezlo iz saobraćaja, pa se vrednost valute određivala prema kursevima raznih stranih valuta. Okupacija Srbije krajem 1915. godine u određenoj meri ugrozila je stabilnost dinara iako je srpska vlada blagovremeno deponovala svoju zlatnu rezervu u vrednosti od 60 miliona franaka u Francuskoj banci u Parizu. ${ }^{5}$ Veći deo dinarskih novčanica, u visini od 300 miliona dinara, ostao je u okupiranoj Srbiji, dok je manji deo iznet iz zemlje $u$ državnim kasama ili u posedu vojnika i izbeglog stanovništva. U okupiranoj državi dinar je brzo iščezao iz opticaja, jer su okupatori propisali nepovoljne privremene paritete za razmenu u relacijama 1 kruna za 2 dinara, 1 bugarski lev za 2 dinara i 1 nemačka marka za 2,5 dinara. ${ }^{6}$ Novac je konvertovao uglavnom samo onaj ko je morao, a kako se količina nametnutog novca konstantno povećavala, novac okupatora preuzeo je celokupan promet, budući da je stanovništvu postalo jasno da je dinar vredniji, te je iščezao iz opticaja. Austrougarske okupacione vlasti proglasile su krunu za zakonsko sredstvo plaćanja i naredile pečatiranje svih dinarskih novčanica u opticaju. Ovu meru stanovništvo je maksimalno izbegavalo, tako da je obeležena nevelika količina novca. Privremenu devalvaciju dinara uprava Vojnog generalnog guvernmana pretvorila je 22 . juna 1916. u stalnu, ali je vrednost dinara i u takvim uslovima ostala veća od krune. U samom Guvernmanu u privatnom sektoru za 100 dinara dobijale su se 102 krune, dok se u Nišu, sedištu bugarske okupacione zone, 100 dinara menjalo za 140 kruna. Čak su i nemački finansijski stručnjaci javno priznavali da je dinar tražena moneta, koja se razmenjuje po kursu koji stalno raste $u$ odnosu na propisani paritet. ${ }^{7}$

${ }^{5}$ Momčilo Zečević, Srbija i valutno pitanje 1918-1921, Zbornik radova Istorijskog instituta, knj. 8, Beograd 1990, 78.

${ }^{6}$ Narodna banka, 96.

${ }^{7}$ Andrej Mitrović, Srbija u Prvom svetskom ratu, Beograd 1984, 395-396. 
Deo novčanica koje su se zatekle u trezoru Narodne banke opljačkan je i poput zaostalih poništenih novčanica pušten u opticaj. Oružani sukob, za koji u početku niko nije smatrao da će trajati dugo, počeo je da ekonomski ruinira sve evropske privrede koje su se našle u ratnom vihoru, da bi od 1916. poprimio oblik ekonomskog iscrpljivanja. Dok su članice Antante imale mogućnost da iz kolonija, bez obzira na opasnost od nemačkih podmornica, dopremaju potreban provijant, ekonomska podrška ratnoj industriji Centralnih sila bila je svakim danom sve manja. U nedostatku zlata, potreba za „zdravim“ devizama bila je velika i do njih je trebalo doći na svaki način. Ukoliko bi to naškodilo finansijskom sistemu protivničke strane, utoliko je rešenje bilo delotvornije. U tu svrhu, Austro-Ugarska je 1917. u Švajcarskoj sprovela „probu“ prodaje nekoliko stotina hiljada dinara do kojih je došla u Srbiji. Međutim, upravo stoga što su novčanice bile žigosane, srpska vlada uspela je blagovremeno da reaguje i spreči mogućnost da se ove novčanice pojave u opticaju, čime je zaštitila vrednost dinara i zavela strogu kontrolu kod komisija za razmenu da bi onemogućila eventualni novi pokušaj. ${ }^{8}$

U egzilu je vrednost dinara prolazila kroz nekoliko faza. Za vreme povlačenja dinar je zadržao svoju vrednost samo u kovanicama u zlatu i srebru, dok je vrednost novčanica bila osetno smanjena i iznosila svega 30$40 \%$ vrednosti u kovanom srebru. Osim situacije u kojoj su se imaoci dinara nalazili pa su bili primorani da pristaju na nepovoljne relacije, ovako nizak kurs mogao bi se objasniti i time što stanovništvo Albanije nije bilo naviknuto na papirni novac, pa se na njegovu vrednost gledalo sa podozrenjem. Kurs dinara u Crnoj Gori bio je daleko povoljniji jer je crnogorska vlada naredila da se novčanica od 10 dinara razmenjuje za 9 perpera, budući da je dinar bio u paritetu sa frankom, a perper sa krunom.

Stacioniranje vlade, vojske i stanovništva u Grčkoj pokrenulo je pitanje odnosa dinara prema drahmi. Vrednost srpske valute na terenu bila je potcenjena u odnosu ne samo na drahmu, već i na franak i liru. Zabrinuti za vrednost dinara i sudbinu građana Srbije koji su ga posedovali, članovi Finansijskog odbora Narodne skupštine na čelu sa Kostom Stojanovićem uputili su Narodnoj banci u Solunu 7. novembra 1915. apel da im se stavi na raspolaganje pola miliona dinara u zlatu i pola miliona dinara u srebru, kojim bi došli do potrebnih količina drahmi, koje bi potom razmenjivali sa izbeglicama u paritetu 7 drahmi za 10 dinara. ${ }^{9}$ Do ovoga, međutim, nije došlo usled približavanja fronta Solunu, pa je sedište Narodne banke premešteno u Marsej. Nešto slično Ministarstvo finansija pokušalo je da uradi

\footnotetext{
${ }^{8}$ Isto, 97.

${ }^{9}$ Isto, 98 .
} 
preko Jonske banke u Atini, ali je ta mera bila kratkotrajna i nije dala konkretne rezultate.

Period nestabilne vrednosti dinara završen je sklapanjem kredita kod saveznika koji su isplaćivani u dolarima i francima. Deo kredita se koristio za razmenu deviza za dinar, pri čemu je utvrđen državni kurs od 80 franaka (88 drahmi) za 100 dinara, kao i mesečni limit dinara koji je lice moglo razmeniti. Ovaj paritet održan je do kraja rata pri komisijama za razmenu i bio je najvažnija valutno-politička mera koja je preduzeta u to vreme. Osim održavanja dinarske vrednosti prema drugim valutama, ova mera uticala je i na poverenje građana u dinarsku novčanicu. Na očuvanje vrednosti dinara uticalo je i energično odupiranje rukovodstva Narodne banke za povećanjem novčaničnog opticaja u inostranstvu. Jedina papirna novčanica koja je odštampana tokom rata bila je 50 dinara, u vrednosti od 51.250.000 dinara. Uskoro je, međutim, počelo njeno povlačenje iz opticaja tako da njen tiraž nije ozbiljnije poremetio odnos papirnih novčanica i njihove podloge. ${ }^{10}$

Zahvaljujući količini metalne podloge, Narodna banka bila je $\mathrm{u}$ mogućnosti da otkuje i stavi u promet srebrni novac sa oznakom 1915. godine u vrednosti od 21.579.766 dinara, što je značilo garanciju vrednosti same po sebi. Potreba za sitnim novcem pokušana je da se reši 1917, ali otkovani nikleni novac nikada nije dospeo do trezora Narodne banke. ${ }^{11}$

Poput belgijske, i srpska valuta bila je uklonjena sa deviznih kotiranja, tako da zvaničnog berzanskog kursa dinara nije bilo. Ukoliko bi se uporedio državni kurs dinara sa odnosom francuskog prema švajcarskom fran$\mathrm{ku}$, vrednost dinara u 1916. bila je 69,20, a u 1917. godini 61,28 švajcarskih franaka za 100 dinara. Kako je, međutim, zamena dinara za franke kod komisije za razmenu bila ograničena na 200 dinara mesečno po osobi, dinari su se mimo komisije menjali privatno, po lošijem paritetu. Ovaj nezvanični kurs, iako se ne može prihvatiti kao potpuno realan, ipak je približniji pravoj vrednosti dinara, koja je pri kraju rata iznosila oko 25 švajcarskih franaka za 100 dinara. ${ }^{12}$ Razlozi lošijeg kotiranja dinara u Švajcarskoj prvenstveno su posledica ratnih zbivanja. Srbija je bila okupirana, a mno-

${ }^{10}$ Ova novčanica izrađena je u Banque de France i pojavila se u opticaju 25. marta 1915. Njeno izdavanje i tiho povlačenje iz opticaja počelo je iste godine, pošto je javnost prezrivo reagovala na njen izgled. Narod je podrugljivo nazvao „pegavac“. - Željko Stojanović, Papirni novac Srbije i Jugoslavije, Beograd 1996, 76.

${ }^{11}$ Od američke kovnice The Gorham Company u Providensu na Long Ajlendu poručene su kovanice od 5, 10 i 20 para. Brodove koji su prevozili novac na Krf potopile su nemačke podmornice $u$ Jonskom moru pa je samo neznatna količina ovog novca dospela $u$ Srbiju, i to posle rata. - Ivica Vučićević, Staniša Novaković, Kovanja i kovnice našeg novca, Numizmatičar, 8, Beograd 1985, 96-97.

${ }^{12}$ Narodna banka, 99. 
štvo izbeglica primorano da menja novac iz egzistencijalnih razloga pod bilo kojim uslovima. Kotiranje dinara svakako nije bilo u skladu sa pokrićem koje su novčanice imale u zlatu, srebru i devizama. ${ }^{13}$

\begin{tabular}{|l|l|l|l|l|l|l|}
\hline \multicolumn{3}{|c|}{ Opticaj } & \multicolumn{4}{c|}{ Podloga } \\
\hline $\begin{array}{l}\text { Novčanice } \\
\text { u zlatu }\end{array}$ & $\begin{array}{l}\text { Novčanice } \\
\text { u srebru }\end{array}$ & Ukupno & Zlato & Srebro & Devize & Ukupno \\
\hline 3.094 .800 & 337.471 .510 & 340.569 .310 & 63.760 .010 & 15.559 .985 & 217.973 .922 & 297.293 .917 \\
\hline
\end{tabular}

Iz tabele se vidi da je podloga dinarskih novčanica pri kraju rata 1918. iznosila čak $87,29 \%$, što znači da je pokrivenost bila gotovo apsolutna.

Dok je Narodna banka zadržala visok stepen samostalnosti u odlučivanju, carskom naredbom iz avgusta 1914. austrougarska vlada bila je ovlašćena da upravlja Austro-ugarskom bankom i odmah je primenila sledeće mere: ukinuto je objavljivanje nedeljnih stanja banke; ukinuta je obaveza održavanja propisanog metalnog pokrića od $40 \%$ i kurseva na bazi pariteta; oslobođena je $5 \%$ poreza na emisiju preko određenog kontingenta; suspendovana je zabrana o davanju državnih zajmova, a uprava banke bila je oslobođena obaveze sazivanja redovnih i vanrednih skupština bančinih akcionara. ${ }^{14} \mathrm{U}$ praksi, ove mere omogućile su zaduživanje države van svake kontrole. U početku je to vršeno posredno, putem konzorcijuma drugih bana$\mathrm{ka}$, da bi vremenom postalo neposredno i nezavisno od raspisivanja javnih zajmova. Kako su plaćanja u inostranstvu vršena zlatom, podloga se konstantno topila, a novčanični opticaj povećavao, mimo pokušaja da se blagajničkim zapisima neutrališu negativne posledice velikih emisija novčanica. Sve navedeno jasno pokazuje da je poslovanje banke bilo krajnje neodgovorno i potpuno stavljeno u službu države, bez obzira na moguće posledice po vrednost nacionalne valute.

Za razliku od srpske vlade koja je svoje zajmove sklapala na strani i u devizama, austrougarski dug bio je gotovo u celosti njen unutrašnji dug, koji je od 19,5 milijardi kruna pre rata 1. novembra 1918. dostigao 127 milijardi kruna, od kojih je 35,5 milijardi bio dug Austrougarskoj banci. ${ }^{15}$ Svaki od delova Monarhije, i austrijski i mađarski, ostvario je po sedam zajmova, a gotovo trećina ih je uzeta od emisione ustanove, što ni u jednoj državi do trenutka primirja nije ni približno ostvareno. Spoljni dug Nemačkoj iznosio je 4,87 milijardi maraka, dok je u neutralnim zemljama obezbeđena suma od 165 miliona zlatnih kruna. ${ }^{16} \mathrm{Na}$ zboru akcionara banke 8 .

\footnotetext{
${ }^{13}$ M. Ugričić, $n$. d., 76.

${ }^{14}$ Isto, 88.

${ }^{15}$ Slavko Šećerov, Naše finansije, Beograd 1926, 9.

${ }^{16}$ Momčilo Ninčić, Naše valutno pitanje, Konferencija održana u klubu beogradskih
} radikala 30-XI-1919, Beograd 1920, 6 
februara 1918. podneseni su računi od početka 1914. do kraja 1917. godine. Konstatovano je povećanje opticaja sa 2.493.000.000 na 18.439.000.000 kruna u 1917, odnosno $740 \%$, dok je metalna podloga spala sa 1.562.000.000 na 381.000.000 kruna, tj. na 24,4\%. Na dan 26. oktobra 1918. odnos podloge i kruna u opticaju bio je sledeći (u hiljadama kruna): ${ }^{17}$

\begin{tabular}{|c|c|c|c|c|c|c|}
\hline \multicolumn{4}{|c|}{ Opticaj } & \multicolumn{3}{c|}{ Podloga } \\
\hline Opticaj & $\begin{array}{l}\text { Obaveze } \\
\text { po viđenju }\end{array}$ & $\begin{array}{l}\text { Blagajnički } \\
\text { zapisi }\end{array}$ & Ukupno & U zlatu & $\begin{array}{l}\text { U srebru } \\
\text { i devizama }\end{array}$ & Ukupno \\
\hline 30.680 .000 & 2.849 .000 & 2.929 .000 & 36.458 .000 & 268.000 & 75.000 & 343.000 \\
\hline
\end{tabular}

Iz tabele se vidi da je podloga opala na svega $0,94 \%$, što u svakom pogledu govori da je vrednost krune bila u agoniji čiji se kraj nije video. Već novembra 1918. u opticaju je bilo 35,5 milijardi, da bi nekoliko meseci kasnije kolalo oko 52 milijarde kruna. ${ }^{18}$ Nestanak Austro-Ugarske značio je i nemogućnost postojanja koncesije Austro-ugarske banke, što je u praksi donelo potpunu nesavesnost u poslovanju i totalnu nebrigu za pokriće novčanica u opticaju. Do kraja 1918. Austro-ugarska banka dala je austrijskoj vladi avans od 2 milijarde, a mađarskoj od 2,7 milijardi kruna i sa tim se i nadalje nije prestajalo. ${ }^{19} \mathrm{Na}$ intervenciju vlade Kraljevine SHS Austro-ugarska banka obećala je da ubuduće neće odobravati kredite pojedinim nacionalnim državama bez pristanka ostalih nacionalnih vlada. Obustavljeno je izdavanje blagajničkih bonova vršenih za račun Austrije i Mađarske, koji su takođe bili pretnja za povećanja emisije novca. To ipak nije donelo bitnije rezultate, jer je lombardovanjem ratnih obveznica ovih vlada ona posredno nastavila da ih kreditira. Rezultat je bio povećanje lombardovanog ratnog zajma sa 4,734 milijardi kruna 31. oktobra 1918. na 7,943 milijardi 23. decembra $1918 .^{20}$ Svoje poteze banka je pravdala time da bi obustava lombarda ratnog zajma dovela do ekonomskog sloma, socijalnih nemira i dala maha boljševizmu i revoluciji. Štampanje starih, a ne kreiranje novih novčanica Austrije i Mađarske, bilo je profitabilnije po ove države, jer bi se zamenom starih novčanica utvrdila njihova količina i nemogućnost konverzije za metalnu podlogu ili devize, što bi ubrzalo bankrot ovih država. Korišćenje starih novčanica održavalo je i ideju monetarne i carinske unije sa novostvorenim državama i očuvanje ekonomsko-finansijskog prostora nekadašnje države, što nije bilo strano ni određenim krugovima novih država, u kojima je postojao strah od finansijske samostalnosti.

\footnotetext{
${ }^{17}$ M. Ugričić, $n$. d., 89.

${ }^{18}$ Narodna banka, 139-140.

${ }^{19}$ M. Ninčić, $n$. d., 6.

${ }^{20}$ Isto, 7.
} 
Sve navedeno jasno pokazuje da su kraj rata i podela Austro-Ugarske doneli državama naslednicama u nasleđe i valutu čija je realna vrednost bila pod velikim znakom pitanja. Uz to, trebalo je izvršiti monetarno razdvajanje između država naslednica, zamenu kruna valutama država naslednica i likvidaciju Austro-ugarske banke. Regulisanje ovih pitanja utvrđeno je članom 206 Ugovora o miru sa Austrijom u Sen Žermenu i članom 189 Ugovora o miru sa Mađarskom u Trijanonu. Odredbe koje su se ticale zamene kruna i likvidacije Austro-ugarske banke propisale su da: države naslednice $u$ roku od dva meseca izvrše obeležavanje kruna na svom području; da se u roku od 12 meseci izvrši zamena kruna u valute država naslednica, prema paritetu koje same utvrde; da se u roku od 14 meseci zamenjene krune predaju Reparacionoj komisiji radi daljeg postupka i da novčanice puštene $u$ opticaj do 27. oktobra 1918. imaju prava na celu aktivu Austro-ugarske banke, a one izdate posle tog datuma imaju prava na obveznice austrijske i mađarske vlade. ${ }^{21}$

Kako je bilo nemoguće utvrditi u kom periodu je izdata koja novčanica, rešenje je pronađeno na taj način što su Austrija i Mađarska priznale ostalim državama forfetarno utvrđene količine zlata iz svojih kvota, ukupno oko 5 miliona zlatnih kruna. Raspodelom aktive Austro-ugarske banke trebalo je da pripadne: Rumuniji 6,1\%, Čehoslovačkoj 6,1\%, Kraljevini SHS 4,27\%, Austriji 4\%, Mađarskoj 4\%, Italiji 2,5\% i Poljskoj 2,15\%. ${ }^{22}$ Kraljevina SHS je posle svih obračuna u stvarnosti primila znatno više od utvrđenog procenta, jer je od čiste aktive koja je iznosila 243 miliona zlatnih kruna dobila preko 36 miliona ili oko 400 miliona dinara. ${ }^{23}$ Poslovi oko likvidacije Austro-ugarske banke završeni su 1924, ali su zlato i devize isplaćivani sve do 1928.

Vlada Kraljevine SHS zabranila je 12. decembra 1918. iznošenje novca iz zemlje, kao i unos iznosa većeg od 1.000 kruna ili leva. ${ }^{24}$ Krune su $\mathrm{u}$ velikim količinama unošene preko računa francuske Istočne armije $u$ Budimpešti, koji je otvoren za plaćanje njenih materijalnih izdataka, od kojih su mnogi ostvareni na tlu Vojvodine. Na intervenciju Ministarstva finansija komanda francuske armije otvorila je tekući račun u Beogradu,

${ }^{21}$ Isto, 90.

${ }^{22}$ Samouprava, 72, 1. april 1922, 9.

${ }^{23}$ Do decembra 1925. primljeno je 35.975.032,37 zlatnih kruna. Tempo isplate bio je sledeći: 17. juna 1921 - 10.000.000; 27. novembra 1922 - 14.665.335,15; 13. novembra 1923 - 5.689.172,07; 15. marta 1924 - 3.519.236; 6. avgusta 1924 - 1.357.507,28 i 18. novembra 1924 - 743.781,87. Tokom 1925. u čekovima je primljeno 121.450,02 dolara, 476.919 francuskih franaka i 50.204,17 funti. Nepokretnosti filijala Austro-ugarske banke koje su pripale Narodnoj banci procenjene su na 2.758 .872 zlatne krune. - AJ, 37-32-237, Izveštaj ministru finansija, 28. novembar 1925.

${ }^{24}$ AJ, 70-3-6, Rešenje A. br. 1263, 12. decembar 1918. 
preko koga su pokrivani izdaci napravljeni na području Kraljevine SHS. Da se u vrednost krune sumnjalo i među običnim svetom, svedoči i njeno krijumčarenje u Kraljevinu SHS. Ono je uzelo maha još u prvoj polovini 1919. i vremenom se sve više širilo. ${ }^{25}$ Istovremeno se pristupilo popisu i žigosanju stranog papirnog novca zatečenog na teritoriji Kraljevine SHS, koja je prva od država naslednica pokrenula nacionalizaciju krunskih novčanica. U želji da se izvrši u što kraćem roku, obeležavanje je obavljao niz finansijskih, policijskih, žandarmerijskih, vojnih, sreskih, opštinskih, bankarskih, sudskih, poštanskih i crkvenih nadleštava. ${ }^{26}$ Korišćeni su različiti pečati koji su otiskivani na različitim delovima novčanica, što je preduzetu meru umnogome učinilo nedelotvornom i kritikovanom u javnosti. Žigosanje je smatrano za primitivan oblik zaštite novca, što i jeste bilo, ali se u zapadnim delovima države moglo čuti i mišljenje da će stanovništvo masovno povući novac iz banaka i da mera može prouzrokovati nemire. Ova predviđanja pokazala su se potpuno pogrešnim, pa i zlonamernim, a „Hrvatski lojd“ je među prvima zabeležio da su ulozi kod banaka osetno narasli, jer je to bio najsigurniji način da će novac biti obeležen i važeći. ${ }^{27}$ Najveći protivnici obeležavanja kruna u stvari su bili privredni krugovi severozapadnog dela države zbog postojećih bankarskih i trgovačkih veza sa Bečom i Budimpeštom.

Obeležavanje kruna trajalo je u Beogradu do 5. januara, a u ostalim krajevima zemlje do 31. januara 1919. Prema zvaničnim podacima Narodne banke žigosano je 5.322.593.215 kruna, odnosno u: Hrvatskoj i Slavoniji 1.948.917.241 (36,6\%); Banatu i Bačkoj 1.668.536.437 (31,4\%); Sloveniji 603.326.472 (11,4\%); Bosni i Hercegovini 512.122.574 (9,6\%); Srbiji 421.017.405 (7,9\%); Dalmaciji 163.060.440 (3\%) i Crnoj Gori 6.612.646 $(0,1 \%) .{ }^{28}$ Ubrzo posle žigosanja krunama je oduzeto prometno važenje na teritoriji Srbije, verovatno sa namerom da se formira jedinstvena valuta na njenoj teritoriji radi olakšanja prometnog, kreditnog i trgovačkog poslovanja. ${ }^{29}$

${ }^{25}$ Koliko je krijumčarenje vremenom uzimalo maha i nesumnjivo govori o stalnom padu vrednosti krune vidi se i iz mera vlade da krijumčarenje spreči. Zakonom iz maja 1919. krijumčarenje je zastupljeno u zajedničkom članu za tu delatnost. U zakonu iz juna 1920. ono dobija zaseban član (181), a zakon iz jula 1921. predviđa čak i nagrade potkazivačima za ovo krivično delo. - Laza Kostić, Adam Maksimović, Zbornik finansijskih zakona od 19191939/40, Novi Sad 1939, 9, 65, 143.

${ }^{26}$ Pečatirane su novčanice od 10, 20, 50, 100 i 1.000 kruna. - Vitomir Sokolović, Žigosanje i markiranje neprijateljskog novca, Filatelista, 170, Beograd 1977, 32-36.

${ }^{27}$ Milorad Nedeljković, Naš valutni problem, Beograd 1919, 16.

${ }^{28}$ M. Nedeljković, Pred rešenje valutnog pitanja, Zagreb 1919, 3. Milan Stojadinović $\mathrm{u}$ referatu pisanom 1925. iznosi podatke da je žigosano u: Banatu, Bačkoj i Baranji 1.664.036.437; Hrvatskoj 1.537.673.858; Sloveniji 686.623.239; Bosni i Hercegovini 510.211.574; Srbiji 418.517.405; Dalmaciji 153.060.440 i Crnoj Gori 5.612.646, odnosno 446.875.616 kruna manje. - AJ, 37-32-238, Valutno pitanje.

${ }^{29}$ AJ, 37-32-238, Valutno pitanje. 
Mogućnost jednostavnog falsifikovanja nije zaustavila unos kruna $u$ zemlju, što direktno ukazuje na to da je vrednost krune u inostranstvu bila niža nego u Kraljevini SHS. Zato je Ministarstvo finansija poručilo određene količine novih banknota od kovnica u Parizu, Pragu i Zagrebu, ali su finansijska situacija u Evropi i potpun poremećaj u novčanim tokovima gotovo svih zemalja uticali da su sve kovnice bile prebukirane tokom 1919, mada je određena količina dinara kao valute Kraljevine SHS bila odštampana. Svest da su krune praktično bezvredan papir kojim se odliva roba iz države i strah da je više od $20 \%$ kruna u opticaju bilo na teritoriji Kraljevine SHS preovladavali su i u Trgovačkoj komori u Beogradu, koja je od Ministarstva trgovine i industrije tražila hitno rešavanje valutnog pitanja. Smatralo se da se problem mora rešiti pre polovine avgusta i početka izvozne sezone, jer bi posedovanje novog kontingenta bezvrednih kruna donelo samo štetu, a ne korist od izvoza. ${ }^{30}$

Radi zaštite od unosa kruna od 26. novembra 1919. do 11. januara 1920. izvršeno je markiranje onih već žigosanih. Na svaku novčanicu lepljena je odgovarajuća markica, slična poštanskoj, osim na apoenima od 1 i 2 krune. Iako se za ove markice, izrađene u Beču, smatralo da se ne mogu falsifikovati, veoma brzo se pojavilo 10 različitih falsifikata. ${ }^{31}$ Markiranje kruna vršeno je u filijalama Austro-ugarske banke, u drugim bankama, sreskim i opštinskim finansijskim upravama. Tokom postupka dolazilo je do niza nepravilnosti i nedoslednosti, jer su lepljene neodgovarajuće markice na banknote, a u zapadnim krajevima markirane su i znatno oštećene novčanice, kao i one koje su, očigledno u brzini, bile odštampane samo sa jedne strane, što je izazvalo niz problema prilikom njihove kasnije zamene. ${ }^{32}$ Prilikom markiranja po Rašinovom planu, primenjenom u Čehoslovačkoj, zadržano je $20 \%$ podnete sume za obeležavanje. Ne računajući sitne apoene, markirano je 5.686.601.730 kruna, odnosno 363.606 .730 više od žigosanih, što je izazvalo burnu reakciju u javnosti, iako je povećanje iznosilo nevelikih $6,8 \%$ jer se krijumčarenje nije moglo sprečiti u potpunosti, o čemu najbolje svedoči primer Čehoslovačke, koja to nije uspela i mimo rigorozne kontrole i drugih mera. ${ }^{33}$

Odluka o nazivu nove valute - dinara doneta je na sednici Ministarskog saveta 1. februara 1919, a dozvola za doštampavanje novca i povlače-

${ }^{30}$ AJ, 65-1083-2058, Pismo Trgovačke komore br. 3356, 27. jun 1919.

${ }^{31}$ Službene novine Kraljevstva Srba, Hrvata i Slovenaca, 36, 18. februar 1920, 3.

${ }^{32}$ Prilikom povlačenja kruna zahtevana je odgovarajuća markica na banknoti, kao i njena neoštećenost. U punom iznosu mogla se zameniti samo ona novčanica koja je bila oštećena do jedne četvrtine površine. - Pravilnik o povlačenju krunskih novčanica, Novi Sad, $4-5$.

${ }^{33}$ AJ, 37-32-238, Valutno pitanje. 
nje kruna data je 15. januara 1920. Prve „krunsko-dinarske“ novčanice predstavljene javnosti 18. januara 1920. nazvane su tim imenom, jer su i imale iskazanu dvostruku vrednost, u dinarima i u krunama. Kako je iznos u krunama bio četvorostruk, time je i objavljen odnos po kome će se krune menjati za nove novčanice, dok je odnos dinara sa novom novčanicom bio al-pari. Zamena kruna otpočela je prvo na prostoru Srbije i Crne Gore i mada je kao krajnji rok za zamenu na prostoru cele države utvrđen 15. mart, zbog obimnosti posla povlačenje kruna završeno je tek 3. juna 1920. Određena količina kruna zamenjena je i posle ovog roka, pošto se Rapalskim sporazumom od 12. novembra 1920. Italija povukla iz određenih delova Istre i Dalmacije. Ove krune povučene su u roku od 20 dana tokom aprila 1921, a suma do 100.000 kruna menjana je u već propisanom odnosu, dok su iznosi veći od tog menjani u relaciji $1: 6 .^{34}$ Povlačenjem kruna iz opticaja država se zadužila kod Narodne banke za 1.194.542.407 dinara. ${ }^{35}$ Ovaj dug država je planirala da otplati zlatom koje je trebalo da joj pripadne iz likvidacione mase Austro-ugarske banke, ali kako dobijena suma nije bila dovoljna, država je otplaćivala dug svojim udelom u dobiti Narodne banke, zaradom od državnih domena u iznosu predviđenom budžetom za taj cilj, vanrednim dotacijama predviđenim budžetom i redovnom otplatom od $1 \%$ godišnje od ostatka duga počev sa šestom godinom od dana stupanja na snagu zakona o Narodnoj banci i $2 \%$ godišnje počev sa devetom godinom. ${ }^{36}$ $\mathrm{Na}$ ovaj način dug je otplaćivan sve do 1931. kada je izvršena zakonska stabilizacija dinara.

Za zadržane krune prilikom razmene izdavane su priznanice na kojima su se nalazili ime i prezime poverioca, adresa i iznos sume. Bilo je predviđeno da se zadržane krune pretvore $u$ unutrašnji zajam sa rokom od 5 godina i sa kamatom od 1\%, ali je konačno rešenje krunskih priznanica regulisano tek članom 15 Finansijskog zakona za 1929/30. po kojem su one mogle da se upotrebe za uplatu duga državi po osnovu poreza do 1926, kao i za plaćanje kazni za finansijske krivice. ${ }^{37}$

Od momenta stvaranja zajedničke države do zamene kruna i dinara Kraljevine Srbije u krunsko-dinarsku novčanicu vodio se pravi rat oko utvrđivanja njihovog međusobnog odnosa i izbora valute Kraljevine SHS. Institucije, mediji i pojedinci iz severozapadnih krajeva države trudili su se da dokažu da je vrednost krune veća od one koja se spominjala u kuloarima ili

${ }^{34}$ AJ, 70-3-6, Pravilnik o povlačenju krunskih novčanica na teritoriji Dalmacije.

35 AJ, 37-32-238, Valutno pitanje. M. Ugričić, $n$. d., 102 navodi da je povučeno 5.121.611.345,20 kruna, odnosno da je izdato 1.280.402.836,30 dinara, dok se u: Narodna banka, 143, navodi da je izdat 1.277.427.121 dinar.

${ }^{36}$ AJ, 37-32-238, Valutno pitanje.

${ }^{37}$ L. Kostić, A. Maksimović, n. d., 25, 33, 121. 
glasilima istočnog dela zemlje, jer su oni prvenstveno bili njeni posednici. Mnoge od tih tvrdnji nisu imale nikakvu realnu podlogu, ili su se oslanjale na delimične povoljnosti koje su odgovarale stavu koji su zastupale. Savez novčanih zavoda Kraljevstva SHS okupljao je 1919. najveći broj banaka iz Hrvatske, Slavonije, Bosne i Hercegovine. ${ }^{38}$ Predlog Saveza početkom avgusta 1919. bio je da se uvede državni dinar kao jedino platežno sredstvo za koje bi pokriće bio celokupan državni domen i za koji bi bile zamenjene krune i srpski dinar. Krune bi bile zamenjene al-pari, pri čemu bi se polovina kruna podnetih na zamenu zadržala i isplatila posle godinu do godinu i po dana, a dobijenim potvrdama mogle bi se plaćati državne obaveze. Dinar Narodne banke zamenjivao bi se po kursu 2:1 sa novim dinarom, jer se krunska novčanica u Srbiji smatrala rekvizicionom priznanicom koja je tokom okupacije nametnuta po dvostruko vrednijem kursu u odnosu na dinar. ${ }^{39}$ Savez je, dakle, bio svestan da je kruna dvostruko više u opticaju od realne potrebe i zato je predlagao zadržavanje polovine sume, a sa druge strane srpski dinar imao bi dvostruku vrednost samo zbog nametnutog odnosa prema kruni u okupiranoj Srbiji. Iako se radi o predstavnicima banaka koji su bili stručni u svojoj oblasti, očigledno je državni domen trebalo da preuzme funkciju podloge valuta, odnosno na taj način izbegnuta je uloga pokrića novčanica metalnom i deviznom podlogom jer je ona neuporedivo bila viša u pogledu srpskog dinara. Sa druge strane, podatak da je prilikom zamene markiranih kruna zadržano 20\% u iznosu od 922 miliona, Savez je iskoristio da naglasi kako je u opticaju „svega“ 3.688 .000 kruna, ne navodeći da su sitni apoeni izuzeti od markiranja, time i od deponovanja petine vrednosti. Konstatovano je da je utvrđen odnos dinara i krune neekonomski motivisan, a za slabljenje krune optuživani su Ministarstvo finansija, Ministarstvo trgovine i industrije i Devizna centrala, ali je ponovljeno da je postojao „višak" kruna koje je trebalo povući iz opticaja da bi ona bila zamenjena al-pari sa novim dinarom. ${ }^{40} \mathrm{U}$ izveštaju, međutim, nije objašnjeno zašto je vrednost krune konstantno padala na inostranim berzama, tamo gde nikakvog uticaja nisu imale institucije Kraljevine SHS. Međutim, čak i kada bi se prihvatila netačna tvrdnja Saveza o 3,6 milijardi kruna u opticaju na prostoru Kraljevine SHS, to bi značilo da je Narodna banka primila zlata za podlogu od svega 1\%. Suprotno tome, dinara u opticaju 31.

${ }^{38}$ Savez je osnovan 25. aprila 1919. u prisustvu delegata hrvatskih, slovenačkih i srpskih banaka. Nastao je od predratnog Saveza hrvatskih novčanih zavoda i krajem 1919. obuhvatao je 102 novčana zavoda. - Izveštaj „Saveza novčanih zavoda Kraljevstva Srba, Hrvata i Slovenaca" u Zagrebu za godinu 1919, Zagreb 1920, 6-7.

${ }^{39}$ Spomenica Saveza novčaničnih zavoda Kraljevstva Srba, Hrvata i Slovenaca, u predmetu novčanične banke i uređenja valute, Zagreb 1919, 18-19.

${ }^{40}$ Izveštaj „Saveza novčanih zavoda Kraljevstva Srba, Hrvata i Slovenaca“ u Zagrebu za godinu 1919, 12. 
decembra 1919. bilo je u vrednosti od 664.007 .469 (i pri navedenoj tvrdnji za krune šest puta manje), sa podlogom od 434.478.617 dinara, odnosno $65,43 \% .{ }^{41}$ Uz to, treba primetiti da količina dinara stavljena u opticaj 1919. gotovo u potpunosti odgovara svoj do tada odštampanoj količini od postanka Narodne banke. Ovo je razumljivo, jer je dinar štampan za potrebe Kraljevine SHS i njenih institucija na celokupnom prostoru, a time i za zajedničke potrebe svog stanovništva, a ne samo onog sa područja Srbije.

Za povoljniji odnos krune prema dinaru zalagalo se i Udruženje vojvođanskih banaka i smatralo je korisnim paritet 1 zlatna kruna za 1 zlatni dinar, odnosno vrednost dinara bila bi 1,25 kruna. ${ }^{42}$ Slično Zavodu i Udruženje je prelazilo preko podloge koja je osnova za merilo vrednosti valuta. U suštini, obe institucije bile su bankarska udruženja koja su imala cilj da svoje pozicije postave $u$ za njih povoljan položaj. Primenjenim rešenjem prilikom razmene kapitali banaka su se smanjivali na četvrtinu, što je u očima bankara bilo nepovoljno rešenje, bez obzira na realnost.

U želji da dokaže veću vrednost krune Obzor je proklamovao sopstvenu ekonomsku teoriju, po kojoj: „Presudna važnost ekonomske funkcije neke novčanice za prosuđivanje iste je $u$ konkretnoj narodnoj privredi - a ne po kursu. (...) Pad jugoslovenske krune na međunarodnom tržištu do markiranja nije u celosti pogoršao njenu kupovnu moć unutar naše narodne privrede.“" ${ }^{33}$ Ovakve tvrdnje nisu uzimale specifičnost ekonomske situacije $\mathrm{u}$ tom trenutku, ali je sam list posredno priznao devalvaciju krune, budući da je potvrdio pad kupovne moći krune, ali da ona nije bila u visini njenog pada vrednosti na berzama. Pozivanje na identičnu kupovnu moć dinara i krune koristio je dve decenije kasnije Rudolf Bićanić da za političke potrebe HSS-a dokaže da su Srbijanci „pokrali ostale“. Prvi argument bio je taj da „ono, što je stajalo u Beogradu i Srbiji 10 dinara, plaćalo se u Zagrebu i Hrvatskoj 10 kruna“, a drugi da „imaoci krunskih novčanica imali su moralno pravo, da od države kod izmjene kruna za dinare onaj tečaj, koji je važio u momentu stvaranja države SHS“, to jest dve krune za jedan dinar. ${ }^{44}$ Osim što je jedan argument $\mathrm{u}$ koliziji sa drugim, budući da prvi označava vrednosti al-pari, a drugi $2: 1$, Bićanićeve tvrdnje bile su manipulacija jer nisu prikazivale realno stanje stvari. Cene proizvoda u devastiranoj Srbiji bile su daleko više od onih krajeva u kojima nije bilo ratnih operacija ili su one bile sa nesrazmerno manjim intenzitetom, tako da pomenuti primer nije realno prikazivao vrednost dinara u odnosu na krunu. Što se tiče odnosa dinara i krune $2: 1$, Bićanić je uzeo kurs ovih valuta u Švajcarskoj kra-

\footnotetext{
${ }^{41}$ Narodna banka, 290-291.

${ }^{42}$ Boris Kršev, Bankarstvo u Dunavskoj banovini, Novi Sad 1998, 49.

${ }^{43}$ Obzor, 11, 16. januar 1920, 3.

${ }^{44}$ Rudolf Bićanić, Ekonomska podloga hrvatskog pitanja, Zagreb 1938, 42-43.
} 
jem rata, s tim da je odnos od 25 franaka za 100 dinara uzeo na osnovu privatnih kurseva (dok je zvanični bio dvostruko veći), a za odnos 12,5 franaka za 100 kruna koristio je zvanični kurs. Da je odnos dinara i krune, koje je specijalnim rešenjima određivalo Ministarstvo finansija, bio povoljan po krunu posredno priznaje i Bićanić, pošto navodi kako je krijumčarenje kruna u Kraljevinu SHS dostiglo sumu od 800 miliona. ${ }^{45}$

Ne mali broj ekonomista zalagao se za različit kurs krune po pokrajinama prilikom zamene. Osnova za takve predloge nalazila se u činjenici da je okupatorska vojska diktirajući kurs krune i cenu životnih namirnica, u stvarnosti rekvirirala namirnice, samo naizgled ih plaćajući. ${ }^{46}$ Osim toga, nametnuti kurs krune od $2: 1 \mathrm{u}$ ratu i prihvatanje bez razlike kursa od $1: 4$ u Kraljevini SHS, značilo je osmostruki gubitak za sve one koju su konvertovali dinare $\mathrm{u}$ krune. ${ }^{47}$ Stojan Protić, bivši ministar finansija Kraljevine Srbije i jedan od radikalskih prvaka, ocenio je da je neprihvatljivo sprovođenje postupka po kojem bi građani Srbije podneli gubitak pri zameni stranog novca. Njegov predlog bio je da se državna uprava izbori da od Centralnih sila dobije onoliku sumu „zdravog“ novca koliko je iznosila gotovina u stranim novčanicama u Srbiji. Kada bi taj novac bio primljen, strane novčanice povlačile bi se isplatom $u$ dinarima. ${ }^{48}$

Mišljenje da je realna vrednost krune manja od usvojene izneo je slovenački advokat i ekspert za valutna pitanja Milko Brezigar. U Ekspozeu o valutnom pitanju koji je podneo na zasedanju Privrednog odseka Narodnog sveta u Ljubljani 21. i 22. oktobra 1918. istakao je da valuta nove države treba da bude dinar, koji je pripadao Latinskoj uniji, a da je efektivna vrednost krune prema dinaru bila između 15-20\% njegove vrednosti. Obrazloženje za ovako nepovoljan kurs krune $\mathrm{u}$ trenutku kada se o tome nije $\mathrm{u}$ javnosti mnogo znalo Brezigar je pronašao $u$ količini novčane cirkulacije. U predratnoj Austriji na 1 stanovnika kolalo je 50 kruna, a 1918. - 560. U jugoslovenskim pokrajinama Austro-Ugarske cirkulisalo je pre rata 380 miliona kruna, dok su 1918. krune dostigle sumu od 4,25 milijardi. Ukoliko bi se ovoj količini dodalo najmanje 500 miliona kruna u Srbiji, inflacija bi

${ }^{45}$ Odnos dinara i „jugo“ krune iznosio je: od novembra 1918. do marta $1919-2$ : 1; od 19. marta do 4. juna $1919-2,5: 1$; od 5 . juna do 12 . novembra $1919-3$ : 1 ; od 12 . novembra do 31. decembra $1919-3,5: 1$ i od 1 . januara 1920 . do definitivne zamene $4: 1$. Kraljevina Srba, Hrvata i Slovenaca, Almanah 1921-1922, Zagreb 1922, deo III, 101.

${ }^{46}$ Milić Radovanović, Naš novčani problem, Zagreb 1920, 16.

${ }^{47}$ Momčilo Ninčić navodi primer Beograđanina koji je zbog potiskivanja dinara iz opticaja tokom okupacije zamenio svojih 40.000 dobivši za njih 20.000 kruna. Izdržavajući se od drugih sredstava dočekao je oslobođenje sa tom svotom i ukoliko bi se propisani odnos primenio, njegov početni kapital bio bi umanjen na svega 5.000 dinara. - M. Ninčić, n. d., 63.

${ }^{48}$ Epoha, 9, 5. januar 1919, 1. 
zaista bila veoma velika. ${ }^{49}$ Istovremeno, kruna je imala tek šestinu predratne kupovne moći, dok su cene porasle gotovo šest puta. Brezigar je zbog toga smatran režimskim čovekom, ali treba istaći da je svoje mišljenje dao u trenutku kada je rat još uvek trajao i da je to mišljenje delio ne mali broj učesnika sednice, među kojima i prvak narodno-napredne stranke Ivan Tavčar koji je izneo mišljenje da je Slovenija preslaba da sama reši svoj valutni problem i da se on može rešiti jedino uz pomoć Srbije.

Veliki rat zahtevao je ogromne troškove, a što je duže trajao to je potreba za novcem bila veća. Mnoštvo civilnih i vojnih blagajni raspolagalo je velikim sumama novca za nabavku ratnog provijanta ili isplatu vojnika. Industrijalcima, trgovcima, a posebno vojnim liferantima bile su potrebne ogromne sume novca za sve potrepštine neophodne vojsci. Time je velika količina novca bila pohranjena u specifične „ekonomske rezervoare" koji su delom bili javni, a delom skriveni i time nisu pritiskali novčanični opticaj. Završetak rata, povratak vojnika kućama, ukidanje ratnih kasa i ustanova, vraćanje privrednog života u mirnodopsku konjunkturu, izazvali su oslobađanje novčanica iz pomenutih "rezervoara" i doveli do panike kod imalaca novčanica i njihove želje da se one što pre zamene za nešto sigurnije, poput robe, nekretnina, hartija od vrednosti, sigurnijih valuta. Tek u tom trenutku počela se osećati realna vrednost novčanica, u ovom slučaju kruna. Do tog momenta, ustanove ili stanovništvo nisu imali mogućnost da sagledaju položaj novčanica koje su imali, a neobjavljivanje stanja Austro-ugarske banke onemogućilo je sagledavanje odnosa novčanica u opticaju i njihove podloge.

Iako je taj odnos bio krajnje nepovoljan po novčanični opticaj, on se i dalje pogoršavao svakodnevnim doštampavanjem za interese Austrije i Mađarske. Zato su sve države naslednice preduzele mere zaštite „svojih" kruna. Način na koji je to učinjeno u Kraljevini SHS nije bio najsrećniji, ali je ipak uspeo da u najvećoj meri blokira svakodnevno ubacivanje kruna susednih država na svoju teritoriju. Pojedine mere, poput markiranja kruna, kritikovali su i državni zvaničnici, poput Momčila Ninčića, koji je smatrao da je to nepotrebna mera ,jer neće sprečiti priliv kruna, a ima izrađenih novih novčanica za zamenu; štetna, jer stvara poremećaj u privrednim odnosima koji se mestimice pretvara u pravu krizu“ ". ${ }^{50}$

Ministarstvo finansija Kraljevine SHS je prvo izvršilo „omeđavanje“ kruna i to žigosanjem. Po ugledu na Čehoslovačku, to je urađeno još jednom, ovoga puta nepotrebno, ali je dalo okvir o količini potrebnih krunskodinarskih novčanica, budući da su vesti o unosu u zemlju u periodu od žigosanja davale apokaliptična predviđanja. Sve ove mere odložile su konačnu

\footnotetext{
${ }^{49}$ M. Zečević, $n$. d., 80.

${ }^{50}$ M. Ninčić, $n$. d., 75.
} 
zamenu, ali ne može se reći da je ona odlagana da bi se oštetili imaoci kruna. Kurs „zvečećih“ kruna je odlukom Komiteta ministara za finansije i saobraćaj od 18. maja 1919. izjednačen sa kursom dinara, jer su one imale podlogu same za sebe. Pre bi se moglo reći da je konačno rešenje odlagano upravo da bi se pomoglo imaocima kruna, jer je bilo „neophodno nužno kod uređenja valute gledati koliko na stranu ekonomsku i financijalnu, toliko i na političku i socijalnu“ ${ }^{51} \mathrm{O}$ ovim činiocima se vodilo računa jer je zamena kruna bez realnog pokrića bila jedan od faktora koji su uticali na inflatorno kretanje dinara Kraljevine SHS.

Pozicije Privilegovane narodne banke Kraljevine Srbije neuporedivo su bile povoljnije od onih Austro-ugarske banke, što je eksplicitno jasno iz svega navedenog. I na sam dan uoči početka zamene krunskih novčanica 31. januara 1920, u mesecu kada je za potrebe cele države odštampano novčanica u vrednosti od oko 50 miliona, pokriće dinara iznosilo je izvanrednih $62,20 \%{ }^{52} \mathrm{U}$ nedostatku novca država jeste pustila u opticaj 300 miliona kruna, uzetih od Austro-ugarske banke radi zamene pohabanih novčanica, ali ta mera nije bitno uticala na realan odnos dinara i krune, kao što to nisu učinili ni dinari odštampani 1919. i krune koje su prošvercovane na područje Kraljevine SHS. Vrednost dinara bila je neuporedivo viša i imala je svoju realnu podlogu za to. Otkud onda toliko prašine da je kruna svesno depresirana a dinar favorizovan, kada su realni gubitnici bili imaoci dinara Kraljevine Srbije, na čiji teret je palo povlačenje kruna? Najviše su o tome polemisale banke sa prostora bivše Austro-Ugarske. Njihov kapital smanjen je konačnim kursom za zamenu, što je bilo nepovoljno po njih. Krivica za takav rasplet događaja nalazi se prvenstveno u lošoj proceni banaka o pravoj vrednosti krune, ali i povezanosti banaka i njihovih komitenata sa tržištem Austrije i Mađarske. U trenutku primirja banke su posedovale novčanice države koja je nestajala i emisione ustanove čija je sudbina bila neizvesna. Bez obzira na to, nije dolazilo do većih pokušaja zamene kruna srpskim dinarom ili nekom drugom valutom jer je u privatnom novčaničnom saobraćaju kurs bio daleko nepovoljniji od zvaničnog, a zbog nesmetanog poslovanja sa okruženjem upravo se u Zagrebu pojavilo protivljenje žigosanju kruna. Ono što je počelo kao finansijsko, veoma brzo preraslo je u političko pitanje i zato se i održalo do današnjih dana. Ujedinjenjem 1918. Srbi su smatrali da su svoje nacionalno pitanje rešili i doživljavali su novu zajednicu za vrednu žrtvovanja. Većina stanovništva nije bila u stanju da shvati šta uopšte znači realna vrednost dinara. Tu vrednost je donekle mogla da nasluti preko poskupljenja jer je posle četvorogodišnje pljačke i uništavanja Srbije sve bilo skupo, a brz oporavak usled demografske katastrofe u ratu

\footnotetext{
${ }^{51}$ Ademaga Mešić, Nacrt za riješenje valutnog pitanja, Zagreb 1920, 5.

${ }^{52}$ Narodna banka, 290-291.
} 
nemoguć. Da to uporedi sa drugim delovima države niti je mogla, niti znala. Tek ponekad mogla su se čuti negodovanja o kursu prilikom zamene novca, temi koja je potpuno prešla $u$ domen politike, najčešće $u$ obliku opovrgavanja izjava da su Srbijanci opljačkali „prečane“". ${ }^{53}$

${ }^{53}$ Posle izjave vlade da nema sredstava za kredite za pomoć postradalima poslanik Mihailo Škorić javno je izrazio nezadovoljstvo time što je vlada našla mogućnost da obezbedi sredstva za kredit namenjen zameni kruna "s one strane Dunava“ po 0,25 dinara koje ne vrede ništa. - Službene novine, 273, 8. decembar 1920, 3-4. 
Ivan M. Becić

FOR THE DINAR OR FOR THE KRUNA - WHO WON, WHO LOSE?

\section{Summary}

Upon its creation, in late 1918, the Kingdom of the Serbs, Croats and Slovenes, had a three different financial and currency systems. Those were of Kingdom of Serbia, Kingdom of Montenegro and Austro-Hungarian Empire. On its territory there was also a huge amount of the occupation currencies, those of the Bulgaria nad the Germany. Mutual state anticipated the creation of the mutual currency. But except for the choice of the currency for the new Kingdom, it was necessary to establish the relations between the existing currency, so that it should be used for the exchange. Central issue was the relation and the exchanging rate between the Serbian Dinar and Austro-Hungarian kruna. The accepted solution and rates were matter of the debates and disputes in economical and political circles in Kingdom of SHS (Yugoslavia) and continued until nowadays, almost a century after. This article provides closer look into different economical standpoints and opinions of the time, as well as the political standpoints and financial analyses of the values of the two currencies during the period of the exchange. 